\title{
Analysis of the Pre-Service Teachers' Academic Stress Based on Their Self-Concept and Personality
}

\author{
Inmaculada García-Martínez ${ }^{1}\left(\mathbb{D}\right.$, Óscar Gavín-Chocano ${ }^{2, *} *$, Samuel P. León ${ }^{2} \mathbb{D}$ and José Luis Ubago-Jiménez ${ }^{3, *} * \mathbb{C}$ \\ 1 Department of Didactics, School Organization, University of Granada, 18071 Granada, Spain; \\ igmartinez@ugr.es \\ 2 Department of Pedagogy, University of Jaén, 23071 Jaén, Spain; sparra@ujaen.es \\ 3 Department of Didactics of Musical, Plastic and Corporal Expression, University of Granada, \\ 18071 Granada, Spain \\ * Correspondence: ogavin@ujaen.es (Ó.G.-C.); jlubago@ugr.es (J.L.U.-J.)
}

Citation: García-Martínez, I.; Gavín-Chocano, Ó.; León, S.P.; Ubago-Jiménez, J.L. Analysis of the Pre-Service Teachers' Academic Stress Based on Their Self-Concept and Personality. Educ. Sci. 2021, 11, 659. https://doi.org/10.3390/ educsci11110659

Received: 28 August 2021

Accepted: 16 October 2021

Published: 20 October 2021

Publisher's Note: MDPI stays neutral with regard to jurisdictional claims in published maps and institutional affiliations.

Copyright: (c) 2021 by the authors. Licensee MDPI, Basel, Switzerland. This article is an open access article distributed under the terms and conditions of the Creative Commons Attribution (CC BY) license (https:// creativecommons.org/licenses/by/ $4.0 /)$.

\begin{abstract}
Self-concept is a key factor in any teaching-learning process in pre-service teachers. However, it could be negatively affected by academic stress, which is constituted by stressors, stress symptoms, and coping strategies. The aim of the study was to determine the relationship between academic stress and self-concept in this population. This was a descriptive, correlational, and crosssectional study. The sample consisted of 1020 university students in education degrees. In relation to sex, it was found that $75.78 \%$ were women and $24.21 \%$ were men. The following instruments were used: Self-concept Form 5 (AF-5), the Big Five Inventory-44 (BFI-44), and the SISCO Inventory of Academic Stress. The results indicated that academic stress increases and self-concept decreases as studies progress; likewise, most of the students perceived high levels of stress. It was concluded that academic stress is inversely related to self-concept in pre-service teachers, a fact that should be taken into account in their initial training. Social-emotional factors and neuroticism have a decisive influence on the future teachers' academic stress.
\end{abstract}

Keywords: academic stress; personality; self-concept; pre-service teachers

\section{Introduction}

Many studies have been dedicated to examining the psychosocial factors of university students with the aim of clarifying the factors that influence their performance and mental health [1-3]. The university stage is characterised by a challenging period, where students must bring into play all the strategies and resources they have to successfully adapt to the new demands of the contexts in which they are living [4]. As students have more psychosocial tools to resolve conflicts, their mental health will be less impacted. Similarly, the qualities and characteristics they hold also directly influence their disposition towards life and, indirectly, will influence how they perform, as well as the patterns they tend to follow in different scenarios. In turn, self-concept is also a very important factor in the understanding of the whole person's development, as well as in the understanding of their thoughts and actions.

For this purpose, this research attempted to jointly address the academic stress, selfconcept, and personality of pre-service teachers with the intention of drawing out their psychosocial profile and moving forward in the reformulation of an efficient teacher.

In the following, the three dimensions of the study are explained separately, with the intention of extracting the main antecedents in each of them.

\subsection{Academic Stress}

Student performance is conditioned by many external factors, such as the teacher, the characteristics of the environment, or the learning opportunities. There are also other internal factors that play an important role, especially personality or academic stress. The 
latter can be defined as the state felt or perceived by the individual as a consequence of the interaction of all the external factors that affect purely academic matters. In those cases in which this state is negative and threatens their psychosocial well-being, it produces in them feelings of "ineptitude" to face different situations of their educational process and even leads to physical and somatic symptoms such as anxiety, eating disorders, loss of the feeling of control of the situation, or insomnia [5]. In terms of academic performance, students who tend to suffer from academic stress tend to be "labelled" as low achievers, tend to show a generalised lack of motivation to study, and may display absenteeism or dropout [6].

Similarly, each person perceives the same situation differently. This fact implies that the uniqueness of the individual, i.e., their personality, self-concept, or frustration tolerance, explains this fact, with individual differences noted in the adaptive capacities shown in situations that threaten their psychosocial well-being [7].

In general terms, current models of stress are based on the individual-context relationship, with a wide variety of stress typologies appearing. In this research, we focus on academic stress, which is derived from educational contexts. In fact, academic stress arises as a consequence of increased demands in the teaching and learning processes, where new challenges appear, for which the student does not feel prepared, which generates discomfort, anxiety, or uneasiness. In the university stage, this event is exponentially increased, as multiple changes arise in teaching approaches, the student-teacher relationship, as well as the adaptation to a new lifestyle, in which new obligations, demands, and lifestyles arise, which "break" with the dynamics that had been developing in previous educational stages [4].

In the analysis of academic stress, it is necessary to consider the stressors that produce this status in students, what are the symptoms manifested as a consequence of this stress, as well as the coping strategies that tend to be used to manage it. Another striking aspect is that these levels of academic stress are not stable over time, i.e., they do not appear once, and they are not always the same but will oscillate depending on the situation and the strategies learned by the student; they can be maintained, increased, or decreased, especially in the first years of their teacher education program [8].

With the intention of reducing academic stress among students, especially in the university stage, it is essential to learn a wide variety of resources and personal strengths to face the obstacles that arise [9]. This conception is based on the belief in providing the individual with opportunities for personal development, by strengthening those areas that are most limiting and that generate negative feelings. This involves empowering the person, trying to optimise personal factors such as a sense of self-efficacy, while giving them the tools they need to make decisions and be self-regulating, with a view to achieving the goals they set for themselves in a satisfactory way [10]. Similarly, these resources will provide them with the confidence to cope with multiple situations and will act as protective factors that will combat those risk factors for the symptoms that characterise academic stress [11].

\subsection{Self-Concept}

Self-concept is a multidimensional construct that has been widely studied in the field of psychology and education. It can be defined as the image that a person has of him/herself in different facets of his/her life. Self-concept involves affective, cognitive, and behavioural aspects [12], so it cannot be defined as an evaluation free of subjectivity. This self-perception responds both to perceived qualities of the person and to their degree of competence to perform various tasks more or less satisfactorily, as well as their ability to cope with and manage the demands and requirements of the environment in which they live [13].

Authors such as Kaur et al. [14] have identified three components within the selfconcept. Firstly, there is the image or identity perceived by the individual about him/herself, that is, the belief that he/she has about the image he/she projects in his/her environment. 
Secondly, there is self-esteem or the value that a person places on him/herself, that is, on his/her qualities, strengths, weaknesses, or feelings. Finally, there is the behavioural component, where the self-concept shapes a person's ways of acting. The hierarchical and multifaceted model of self-concept considers that the overall self-concept consists of four dimensions [15]: the academic self-concept, the social self-concept, the emotional self-concept, and the physical self-concept.

In our study, the focus was on the academic self-concept, considering its important role in student achievement in line with previous studies [16]. Logically, a person's self-concept will have an impact on his or her performance. In the educational context and with a view to achieving higher levels of academic success, it is necessary for students to have a strong self-concept, reflecting their potential, in order to gain the self-confidence and self-assurance they need to acquire the competences and skills they require to pass their period of education. In the case of students undertaking education degrees, this is of vital importance as their future personal development will impact on the development of their students. However, some previous studies have shown that they tend to have an average or low self-concept [17], which may have a negative impact on their future students.

Specifically at the university level, possible causes that may lead to a low self-concept in this population are the increased difficulty and intensity of the training programmes, where students observe a "high jump" with respect to previous educational stages, which generates a significant amount of (academic) stress [18-20].

\subsection{Personality}

An individual's personality is another factor that determines individual differences. There are multiple models over the decades that have compiled multiple studies with the intention of examining and responding to people's reactions and extracting behavioural patterns based on their personality traits. In recent years, the Big Five personality model has stood out [21]. Based on this approach, peoples' personalities can be explained through five major personality trait, highlighting: extraversion as an individual's ability to relate to others and socialise; agreeableness, which is understood in terms of kindness and sympathy; conscientiousness, which is the ability to be goal-oriented and to organise a plan of action; neuroticism, which corresponds to people's susceptibility to stress and adverse feelings; and openness to experience, which corresponds to creativity and the ability to generate ideas and enjoy aesthetics. From the conjugation of these five main personality domains, it is possible to provide a conceptual framework where different personality types are explained [22]. Previous studies have examined the relationship between personality and stress, which found positive relationships between one of its traits, neuroticism, and the predisposition to stress [23-25]. A recent meta-analysis developed by $\mathrm{Chu}$ et al. [26] regarding personality traits found that agreeableness, extraversion, and openness to experience negatively predict the psychological response to stress. However, they found that conscientiousness positively predicts stress.

Additionally, previous studies suggest that personality plays an important role in the prediction of subjects' well-being due to its relation to how people react to stimuli and events in a wide range of daily situations and contexts $[27,28]$.

\subsection{Our Study}

Having established this problem, the research questions emerged as follows:

- How do psychosocial factors such as self-concept and personality influence pre-service teachers' academic stress?

- Are there differences between men and women in relation to the variables described?

The present study aimed to examine the academic stress of pre-service teachers in terms of their levels of self-concept and the five personality factors. It also examined the constructs studied in terms of gender, with a view to determining whether there were differences in the sample used. 


\section{Materials and Methods}

\subsection{Subjects and Design}

A descriptive, cross-sectional, and non-experimental research project was carried out with 1020 university students in education degrees. In relation to sex, it was found that $75.78 \%$ were women and $24.21 \%$ were men. Regarding age, the ages ranged from 17 to 50 years, with $21.52 ; 4.44$. With regard to the specializations they were studying, $42.8 \%$ were enrolled in primary education; $30.7 \%$ were studying early childhood education; $14.4 \%$ were in social education; $10.4 \%$ were studying for a master's degree in teaching; and 1.7\% were studying pedagogy. Regarding the course, it was found that $57.2 \%$ were enrolled in the first year; $9.9 \%$ were in the second; $18.7 \%$ were in the third; and $14.2 \%$ were in the fourth. Finally, in relation to Spanish location, it was found that $56.5 \%$ were studying in Jaén, followed by Granada (13.1\%), Córdoba (10.4\%), Seville (5.5\%), Cádiz (5.4\%), Málaga (4.2\%), Almería (2.7\%), and Huelva (2.2\%).

\subsection{Instruments}

- Self-concept Form 5-AF5 [29]. This instrument consists of 30 items and measures five dimensions of self-concept: academic, social, emotional, family, and physical, with six items for each of them. The academic self-concept refers to the student's perceived role performance; the social self-concept refers to the perception of performance in social relationships; the emotional self-concept focuses on the emotional state and the involvement and commitment with daily life; the family self-concept aims at integration with the family; and the physical self-concept focuses on the perception of the student's appearance and physical condition [29]. It is answered according to a scale from 1 (totally disagree) to 99 (total degree of agreement). The internal consistency of the scale according to the authors was the following depending on the factors established using the Cronbach alpha coefficient of academic/work: 0.88; social: 0.69 ; emotional: 0.73 ; family: 0.76 ; and physical: 0.74 . Cronbach's $\alpha$ total scale was 0.81 .

- $\quad$ Big Five Inventory-44 [22]. It is a self-report test and measures the five main personality factors, which are extraversion, agreeableness, conscientiousness, neuroticism, and openness to experience. It is composed of 44 items with Likert-type responses ranging from 1 (total agreement) to 5 (total disagreement). This instrument was designed simultaneously in English and Spanish. The reliability analysis ( $\alpha$ Cronbach) of this scale was for each of the corresponding factors of: extraversion $(\alpha=0.69)$, agreeableness: $(\alpha=0.75)$, conscientiousness $(\alpha=0.74)$, neuroticism $(\alpha=0.75)$, and openness to experience $(\alpha=0.77)$.

- $\quad$ SISCO Inventory of Academic Stress [19]. This instrument is a self-report, which requires no more than $10 \mathrm{~min}$ to be filled in. It includes 31 items with five answer options, namely 1 (never) and 5 (always). It identifies three categories: stressful situations, reactions, and strategies, with a reliability that was established using the Cronbach alpha of 0.9 overall and 0.87 for half of them. A range of academic situations involving stress is presented with the aim of analysing how stressful it is for students. It also measures the frequency in which people experience a set of psychological, physiological, and behavioral reactions when faced with these situations. Finally, the instrument evaluates the use of a variety of coping strategies used to address stress.

\subsection{Procedure}

The instruments were administered using the Google Form tool. The researchers attended the classes of the potential participants to explain the purpose of the research. In those cases where it was not possible, the teaching staff were informed to transfer the information to their students and provide them the link to complete the questionnaire. In all cases, the emails of the researchers were provided for contact in case of doubts or further information. Additionally, all participants had to be student teachers as an inclusion criteria. One-thousand one-hundred and fifty participants were invited to participate, of whom 
119 declined to participate or did not answer, and 16 questionnaires had to be removed for not being properly completed. Participation in the study was completely voluntary, in accordance with the Declaration of Helsinki in 1975 and its next adjustment from Brazil in 2013 [30]. This research was approved by the Ethics Committee of the University of Jaén (Reference: OCT.20/1.TES).

\subsection{Data Analysis}

All analysis in this study was conducted with IBM SPSS 25.0 software. The $\alpha$ value for all statistical tests was set to 0.05 . Data Screening was performed before the factorial analysis to evaluate the distribution of data and assumptions. The magnitude of the differences or effect size was determined using Cohen's standardized measure $d$ and was interpreted as zero (0-0.19), low (0.20-0.49), moderate (0.50-0.79), or high $(\geq 0.80)$. Therefore, for each effect size, the $95 \%$ confidence interval (95\% CI) was calculated. In order to understand differences between two correlations, the effect size was calculated with Cohen's q. Both correlations were converted to Fisher's $\mathrm{Z}$ and subtracted from each other. This measure can be interpreted as: $\leq 0.1$ (no effect), 0.1-0.3 (small effect), 0.3-0.5 (medium effect), and $\geq 0.5$ (large effect).

\section{Results}

\subsection{Correlational Analysis}

With regard to the correlation analyses (see Table 1), the following relationships between academic stress and personality traits were shown: academic stress shows a positive relationships with agreeableness, conscientiousness, and neuroticism $(r=0.07$; $r=0.09 ; r=0.26)$. In terms of the relationships between academic stress and self-concept dimensions, positive relationships were found with emotional self-concept $(r=0.32)$ and negative relationships with physical self-concept $(\mathrm{r}=-0.11)$.

Table 1. Means, standard deviations, and correlations between measures.

\begin{tabular}{|c|c|c|c|c|c|c|c|c|c|c|c|}
\hline & 1 & 2 & 3 & 4 & 5 & 6 & 7 & 8 & 9 & 10 & 11 \\
\hline 1 AST & - & & & & & & & & & & \\
\hline $2 \mathrm{EX}$ & 0.06 & - & & & & & & & & & \\
\hline $3 \mathrm{AG}$ & $0.07 *$ & $0.34 * *$ & - & & & & & & & & \\
\hline $4 \mathrm{CO}$ & $0.09 * *$ & $0.38^{* *}$ & $0.42^{* *}$ & - & & & & & & & \\
\hline $5 \mathrm{NE}$ & $0.26 * *$ & 0.30 ** & $0.39 * *$ & $0.37^{* *}$ & - & & & & & & \\
\hline $6 \mathrm{OP}$ & 0.03 & $0.43 * *$ & $0.33^{* *}$ & $0.41^{* *}$ & $0.24 * *$ & - & & & & & \\
\hline 7 AS & 0.01 & 0.13 ** & 0.01 & 0.02 & -0.00 & $0.18^{* * *}$ & - & & & & \\
\hline 8 ES & $0.32 * *$ & 0.00 & -0.00 & 0.01 & $0.19^{* *}$ & -0.08 ** & $0.32 * *$ & - & & & \\
\hline $9 \mathrm{FS}$ & -0.04 & 0.04 & -0.55 & -0.03 & -0.05 & 0.00 & -0.04 & $0.14^{* *}$ & - & & \\
\hline $10 \mathrm{PS}$ & -0.11 ** & $0.14 * *$ & 0.03 & -0.22 & $-0.08^{* *}$ & $0.14 * *$ & $-0.11^{* *}$ & -0.08 ** & 0.27 & - & \\
\hline $11 \mathrm{SS}$ & -0.14 & $0.09 * *$ & 0.03 & 0.00 & -0.02 & 0.03 & -0.01 & 0.27 ** & 0.31 & $0.28 * *$ & - \\
\hline $\mathrm{M}$ & 3.56 & 26.72 & 27.91 & 30.16 & 24.30 & 33 & 22.63 & 18.57 & 21.22 & 19.66 & 21.25 \\
\hline S.D. & 1 & 3.13 & 3.28 & 3.65 & 3.25 & 5.20 & 4.59 & 5.24 & 3.45 & 5.22 & 3.86 \\
\hline
\end{tabular}

Note: ${ }^{*} p \leq 0.01 ;{ }^{* *} p \leq 0.05$. AST: academic stress; EX: extraversion; AG: agreeableness; CO: conscientiousness; NE: neuroticism; OP: openness to experience; AS: academic self-concept; ES: emotional self-concept; FS: familiar self-concept; PS: physical self-concept; SS: social self-concept.

\subsection{Regression Analysis}

Looking at the relationship between academic stress, personality traits, and selfconcept, a hierarchical regression analysis was performed (see Table 2). We used the stepwise method and entered each independent variable into the model individually. In the first equation, gender, age, province, and course were entered as predictors. In this first phase, gender explained 3\% of the variance in academic stress. Females reported higher academic stress than males. In the second equation, personality traits were introduced as independent variables. In this case, $7 \%$ of the variance of academic stress was explained by the neuroticism variable. Thus, subjects with high levels of neuroticism reported higher academic stress. In the third equation, self-concept dimensions were entered as 
independent variables. In this case, $10 \%$ of the variance was explained by the self-conceptemotional variable. Subjects who scored high on emotional self-concept reported high academic stress.

Table 2. Hierarchical regression analysis predicting academic stress.

\begin{tabular}{|c|c|c|c|c|c|}
\hline (Criteria: Academic Stress) & $\mathbf{R}^{2}$ & F & $\beta$ & $p$ & $\Delta \mathrm{R}^{2}$ \\
\hline Demographic factor & 0.03 & 9.19 & & & 0.03 \\
\hline Sex & & & 0.16 & $0.00 * *$ & \\
\hline Age & & & 0.00 & 0.84 & \\
\hline Province & & & 0.03 & 0.23 & \\
\hline Course & & & 0.04 & 0.18 & \\
\hline Personality trait & 0.10 & 12.32 & & & 0.07 \\
\hline Extraversion & & & 0.00 & 0.81 & \\
\hline Agreeableness & & & -0.01 & 0.63 & \\
\hline Conscientiousness & & & 0.00 & 0.86 & \\
\hline Neuroticism & & & 0.27 & $0.00 * *$ & \\
\hline Openness & & & -0.01 & 0.67 & \\
\hline Self-concept & 0.17 & 12.52 & & & 0.10 \\
\hline Academic & & & 0.00 & 0.80 & \\
\hline Emotional & & & 0.28 & $0.00 * *$ & \\
\hline Familiar & & & -0.04 & 0.14 & \\
\hline Physical & & & -0.03 & 0.37 & \\
\hline Social & & & -0.06 & 0.07 & \\
\hline
\end{tabular}

Finally, in order to examine differences in the variables studied, we dichotomised the sample according to gender (see Table 3).

In the academic stress variable, statistically significant differences were found, where women showed higher levels of stress than men ( $\mathrm{M}=3.66 \mathrm{vs.} \mathrm{M}=3.25) ; F(1,1019)=33.55$; $p \leq 0.00$. Regarding the Big Five variables, differences were found in extraversion, whereas men showed higher levels of extraversion than women ( $\mathrm{M}=27.34$ vs. $\mathrm{M}=26.52)$; $F(1,1019)=12.74 ; p \leq 0.00$. In agreeableness, men scored higher compared to women $(\mathrm{M}=28.32$ vs. 27.77$) ; F(1,1019)=5.27 ; p \leq 0.02$. In conscientiousness, men had higher scores than women $(\mathrm{M}=30.54$ vs. $\mathrm{M}=30.04) ; F(1,1019)=3.57 ; p \leq 0.05$. In openness to experience, men also scored higher than women $(\mathrm{M}=33.59$ vs. $\mathrm{M}=32.81) ; F(1,1019)=4.25$; $p \leq 0.03$. With respect to the self-concept variables, the following significant differences were found in the emotional self-concept where women scored higher than men $(M=19.46$ vs. 15.78); $F(1,1019)=101.44 ; p \leq 0.00$. On the contrary, in the physical self-concept, men scored higher $(M=22.05$ vs. $M=18.90) ; F(1,1019)=73.04 ; p \leq 0.00$. Similarly, in the social self-concept, men also scored higher than women $(M=21.69$ vs. $M=21.12)$; $F(1,1019)=4.09 ; p \leq 0.04$. 
Table 3. Means, standard deviations, and sex differences.

\begin{tabular}{|c|c|c|c|c|c|c|c|c|c|}
\hline Variables & Sex & $\mathbf{N}$ & $\mathbf{M}$ & S.D. & $F$ & $p$ & Sig. (Bilateral) & $\begin{array}{l}\text { ES } \\
\text { (d) }\end{array}$ & $95 \% \mathrm{CI}$ \\
\hline \multirow{2}{*}{ Academic Stress } & Men & 247 & 3.25 & 1.10 & \multirow{2}{*}{33.55} & \multirow{2}{*}{0.00} & \multirow{2}{*}{$0.00 * *$} & \multirow{2}{*}{0.161} & \multirow{2}{*}{$(-0.111 ; 0.433)$} \\
\hline & Women & 773 & 3.66 & 0.94 & & & & & \\
\hline \multirow{2}{*}{ BFI-Extraversion } & Men & 247 & 27.34 & 3.15 & \multirow{2}{*}{12.74} & \multirow{2}{*}{0.00} & \multirow{2}{*}{$0.00 * *$} & \multirow{2}{*}{0.114} & \multirow{2}{*}{$(-0.158 ; 0.386)$} \\
\hline & Women & 773 & 26.52 & 3.14 & & & & & \\
\hline \multirow{2}{*}{ BFI-Agreeableness } & Men & 247 & 28.32 & 3,39 & \multirow{2}{*}{5.27} & \multirow{2}{*}{0.01} & \multirow{2}{*}{$0.02 *$} & \multirow{2}{*}{0.119} & \multirow{2}{*}{$(-0.153 ; 0.392)$} \\
\hline & Women & 773 & 27.77 & 3.24 & & & & & \\
\hline \multirow{2}{*}{$\mathrm{BFI}-$ Conscientiousness } & Men & 247 & 30.54 & 3.58 & \multirow{2}{*}{32.57} & \multirow{2}{*}{0.04} & \multirow{2}{*}{$0.05 *$} & \multirow{2}{*}{0.157} & \multirow{2}{*}{$(0.007 ; 0.553)$} \\
\hline & Women & 773 & 30.04 & 3.66 & & & & & \\
\hline \multirow{2}{*}{ BFI-Neuroticism } & Male & 247 & 24.34 & 3.16 & \multirow{2}{*}{.05} & \multirow{2}{*}{0.54} & \multirow{2}{*}{0.82} & \multirow{2}{*}{0.328} & \multirow{2}{*}{$(0.055 ; 0.602)$} \\
\hline & Women & 773 & 24.29 & 3.28 & & & & & \\
\hline \multirow{2}{*}{ BFI-Openness to experience } & Men & 247 & 33.59 & 5 & \multirow{2}{*}{4.25} & \multirow{2}{*}{0.01} & $0.03 *$ & 0.076 & $(-0.115 ; 0.429)$ \\
\hline & Women & 773 & 32.81 & 5.25 & & & & & \\
\hline Academic & Men & 247 & 22.26 & 4.25 & 2.11 & 0.08 & 0.14 & 0.213 & $(-0.196 ; 0.348)$ \\
\hline & Women & 773 & 22.75 & 4.69 & & & & & \\
\hline Emotional & Men & 247 & 15.78 & 4.89 & 10144 & 000 & $0,00 * *$ & 0.112 & $(0.015 \cdot 0.853)$ \\
\hline selt-concept & Women & 773 & 19.46 & 5.04 & & & & & \\
\hline Familiar & Men & 247 & 21.55 & 3.52 & 2.94 & 0.17 & 0.08 & 0.312 & $(0.141 ; 0.424)$ \\
\hline Selt-concept & Women & 773 & 21.12 & 3.42 & & & & & \\
\hline Physical & Men & 247 & 22.05 & 4.88 & 73.04 & 0.00 & $0.00 * *$ & 0.230 & $(0.241 ; 0.474)$ \\
\hline sent-concept & Women & 773 & 18.90 & 5.09 & & & & & \\
\hline Social & Men & 247 & 21.69 & 3.95 & 4.09 & 0.02 & $0.04 *$ & 0.413 & $(0.139 \cdot 0.688)$ \\
\hline Sel & Women & 773 & 21.12 & 3.82 & & & & & \\
\hline
\end{tabular}

Note: effect size Cohen's d (ES); 95\% confidence interval (CI); ${ }^{*} p<0.05 ;{ }^{* *} p<0.00$.

\section{Discussion}

The purpose of this study was to analyse the academic stress levels of pre-service teachers in terms of their self-concept and personality traits, which were obtained from the Big Five model. This analysis aimed to make progress in obtaining the psychosocial profile of this group of pre-service teachers. In general terms, it was found that gender was a variable that influenced the individual differences of the participants surveyed. Other studies argue that high levels of academic stress may be explained by emotional competences, as well as other psychosocial factors that may predispose the individual to manage different challenging situations more or less successfully [13].

In this regard, the literature has found that the introduction of mindfulness-based programmes contributes to achieving emotional stability in students, even reporting increases in academic results [31-33]. Focusing on students' emotional stability implies assuming the important role it plays in coping with different situations and in the development of action guidelines to resolve situations that may threaten their stability. According to these beliefs, it is not merely necessary to teach students from all educational levels these strategies to achieve their full development [34], but teachers' knowledge of them will be crucial for them to be able to transfer them to their students and to be able to build the right conditions to implement the instructional processes as well as to strengthen the social side of the students [35]. Taking into account the correlational results, it was found that individuals who obtained higher scores in agreeableness, conscientiousness, or neuroticism had higher levels of stress. This relationship confirms how different personality traits have a direct impact on student performance, which leads to an increase in academic stress. It also focuses on the need to teach university students skills that allow them to self-regulate and work on their personality strengths [36].

In turn, there are studies that have inversely related neuroticism to emotion regulation [37]. This relationship opens the way to examining the potential of training in this attribute to strengthen the individuals in their lives in general and in the educational 
context in particular [38,39], regardless of the individual's basic personality traits. This finding has implications for education, in terms of incorporating programmes in these constructs into initial and in-service teacher training in order to be able to carry out their professional performance successfully.

On the one hand, students with higher levels of physical self-concept have lower levels of academic stress. This may be due to the fact that the physical self-concept is linked to a higher level of physical activity and, therefore, a release of stress [40]. Additionally, having a higher physical self-concept makes the neurotic personality trait less frequent [41]. Recent research has found that physical activity increased participants' awareness of their health status and decreased unhealthy neuroticism [42].

In terms of gender, our study has reported differences in the different dimensions of self-concept, with men who scored higher in family and social self-concept. In this regard, there are studies such as the one developed by Hay and Ashman [43] who analysed adolescents' self-concept from the perspective of relationships with family and peer groups. They found that men needed a stronger relationship with their parents to maintain their emotional stability compared with women. At the same time, they found that as adolescents grew older, they needed a stronger relationship with their peer group than with their family to achieve emotional stability.

In the present study, it was found that participants with higher levels of emotional self-concept had higher levels of academic stress. These data differ to some extent from the findings of Trigueros et al. [44] who suggest that university students with greater emotional control have higher levels of resilience and, therefore, lower levels of anxiety and academic stress.

Regression analysis shows that women have higher academic stress than men, as is illustrated in studies such as those by Karaman et al. [45] and Teixeira et al. [46]. Likewise, and taking into account academic stress, the most influential factor is neuroticism, as it is a trait typical of people who tend to think negatively about everything they experience [47-49].

Another factor found to be a predictor of academic stress was emotional self-concept. These data differ from previous research such as the study conducted by De la Fuente et al. [50] who found that students with a high emotional component have lower stress rates. This may be due to the fact that knowledge and regulation of emotions help students to reduce stressful situations caused by academic demands $[18,51]$.

The present study also had a number of limitations, such as the characteristics of the sample. In this regard, the focus was placed on future teachers, and it would be interesting to make a comparison between pre-service and in-service teachers in order to see the evolution of the variables. Another aspect to bear in mind is the opportunity provided by this research to get to know the personality traits of pre-service teachers and to be able to implement an intervention to promote those personal aspects that are more likely to change.

\section{Conclusions}

The possession of socio-emotional skills is a critical element for the comprehensive development and well-being of people in general and pre-service teachers in particular. Taking into account the feminisation of the teaching professions, we found that a large percentage of pre-service teachers have high levels of academic stress. This fact may hinder their academic performance during their training period, as well as their future professional performance in the classroom. For this reason, it is necessary to design interventions aimed at providing pre-service teachers with the tools and strategies they need, not only to self-regulate but also to successfully manage challenging situations that may affect their future students. It also argues for the implementation of programmes aimed at strengthening the emotional stability of students, through self-regulation and coping strategies with the intention of achieving socio-emotional wellbeing in students, as well as their comprehensive development in the different environments in which they 
develop. Thus, longitudinal research will be necessary to find out the causes, risk factors, and opportunities found within the training context in order to overcome this situation.

Author Contributions: Conceptualization, I.G.-M. and J.L.U.-J.; Methodology, Ó.G.-C.; software, S.P.L.; validation, S.P.L.; formal analysis, I.G.-M.; writing-original draft preparation, I.G.-M. and Ó.G.-C.; writing—review and editing, I.G.-M., S.P.L. and J.L.U.-J.; supervision, I.G.-M., Ó.G.-C., S.P.L. and J.L.U.-J. All authors have read and agreed to the published version of the manuscript.

Funding: This research received no external funding.

Institutional Review Board Statement: The study was conducted according to the guidelines of the Declaration of Helsinki, and approved by the Ethics Committee of University of Jaén (Reference: OCT.20/1.TES).

Informed Consent Statement: Informed consent was obtained from all subjects involved in the study.

Acknowledgments: The research is included within the Ibero-American Network for the Development of Professional Teaching Identity.

Conflicts of Interest: The authors declare no conflict of interest.

\section{References}

1. García-Martínez, I.; Landa, J.M.A.; León, S.P. The Mediating Role of Engagement on the Achievement and Quality of Life of University Students. Int. J. Environ. Res. Public Health 2021, 18, 6586. [CrossRef]

2. Caballero-Domínguez, C.; Suarez-Colorado, Y. Tipologías distintivas de respuestas ante el estrés académico en universitarios: Un análisis de clasificación. Duazary 2019, 16, 245-257. [CrossRef]

3. Lipson, S.K.; Lattie, E.G.; Eisenberg, D. Increased rates of mental health service utilization by U.S. col-lege students: 10-year populationlevel trends (2007-2017). Psychiatr. Serv. 2019, 70, 60-63. [CrossRef] [PubMed]

4. García-Martínez, I.; Pérez-Navío, E.; Pérez-Ferra, M.; Quijano-López, R. Relationship between Emotional Intelligence, Educational Achievement and Academic Stress of Pre-Service Teachers. Behav. Sci. 2021, 11, 95. [CrossRef] [PubMed]

5. Wunsch, K.; Kasten, N.; Fuchs, R. The effect of physical activity on sleep quality, well-being, and affect in academic stress periods. Nat. Sci. Sleep 2017, 9, 117. [CrossRef] [PubMed]

6. Silva-Ramos, M.F.; López-Cocotle, J.J.; Meza-Zamora, M.E.C. Estrés académico en estudiantes universitarios. Investig. y Cienc. de la Univ. Autón. de Aguascalientes 2020, 28, 75-83.

7. Domingues Hirsch, C.; Devos Barlem, E.L.; De Almeida, L.K.; Tomaschewski Barlem, J.G.; Lerch Lunardi, V.; Marcelino Ramos, A. Stress triggers in the educational environment from the perspective of nursing students. Texto Context. Enferm. 2018, 27, e0370014.

8. Luna, D.; García-Reyes, S.; Soria-González, E.A.; Avila-Rojas, M.; Ramírez-Molina, V.; García-Hernández, B.; Meneses-González, F. Estrés académico en estudiantes de odontología: Asociación con apoyo social, pensamiento positivo y bienestar psicológico. Investig. en Educ. Méd. 2020, 9, 8-17. [CrossRef]

9. Freire, C.; Ferradás, M.D.M.; Núñez, J.C.; Valle, A.; Vallejo, G. Eudaimonic well-being and coping with stress in university students: The mediating/moderating role of self-efficacy. Int. J. Environ. Res. Public Health 2019, 16, 48. [CrossRef]

10. Komarraju, M.; Nadler, D. Self-efficacy and academic achievement: Why do implicit beliefs, goals, and effort regulation matter? Learn. Individ. Differ. 2013, 25, 67-72. [CrossRef]

11. Liu, C.; Li, H. Stressors and stressor appraisals: The moderating effect of task efficacy. J. Bus. Psychol. 2018, 33, 141-154. [CrossRef]

12. Lira, C.J.; Peinado, J.E.; Solano-Pinto, N.; Ornelas, M.; Vega, H.B. Relationships between Self-Concept and Psychological Well-Being in Mexican University Women Students. Rev. Iberoam. de Diagn. y Evalua.-e Aval. Psicol. 2020, 2, 59-70. [CrossRef]

13. Hyseni Duraku, Z.; Hoxha, L. Self-esteem, study skills, self-concept, social support, psychological distress, and coping mechanism effects on test anxiety and academic performance. Health Psychol. Open 2018, 5. [CrossRef] [PubMed]

14. Kaur, J.; Rana, J.S.; Kaur, R. Home Environment and Academic Achievement as Correlates of Self-concept among Adolescents. Stud. Home Community Sci. 2009, 3, 13-17. [CrossRef]

15. Shavelson, R.J.; Hubner, J.J.; Stanton, J.C. Self-concept: Validation of construct interpretations. Rev. Educ. Res. 1976, 46, 407-441. [CrossRef]

16. Guay, F.; Pantano, H.; Boivin, M. Autoconcepto académico y logro académico: Perspectivas del desarrollo sobre su ordenamiento causal. Diario de Psic. Educ. 2003, 95, 124-136.

17. Shrestha, K.; Limbu, S.; Twati, S.; Shrestha, P. Study of self-esteem of nursing students in a nursing college in Kathmandu. Glob. J. Med. Public Health 2018, 7, 1-8.

18. Chacón-Cuberos, R.; Olmedo-Moreno, E.M.; Lara-Sánchez, A.J.; Zurita-Ortega, F.; Castro-Sánchez, M. Basic psychological needs, emotional regulation and academic stress in university students: A structural model according to branch of knowledge. Stud. High. Educ. 2019, 1421-1435. [CrossRef] 
19. Barraza, A. El Inventario SISCO del Estrés Académico [SISCO Inventory of academic stress]. Investig. Educ. Duranguense 2007, 7 , 90-93. Available online: https: / / dialnet.unirioja.es/servlet/articulo?codigo=2358921 (accessed on 20 October 2019).

20. Cherry, M.L.; Wilcox, M.M. Decreasing perceived and academic stress through emotion regulation and nonjudging with trauma-exposed college students. Int. J. Stress Manag. 2020, 27, 101-110. [CrossRef]

21. Tupes, E.C.; Christal, R.E. Recurrent personality factors based on trait ratings. J. Personal. 1992, 60, 225-251. [CrossRef] [PubMed]

22. Benet-Martínez, V.; Johnson, O.P. Los Cinco Grandes across cultures and ethnic groups: Multitrait multimethod analyses of the Big Five in Spanish and English. J. Person. Soc. Psych. 1998, 75, 729-750. [CrossRef]

23. Vollrath, M.; Torgersen, S. Personality types and coping. Person. Ind. Diff. 2000, 29, 367-378. [CrossRef]

24. Nandrino, J.L.; Réveillère, C.; Sailly, F.; Moreel, V.; Beaune, D. Sensibilité aux tracas quotidiens et personnalité des étudiants: Importance du facteur Névrosisme [Sensitivity to daily hassles and student personality: Importance of the Neuroticism factor]. Eur. Rev. Appl. Psych. 2003, 53, 239-244.

25. Matthews, G.; Deary, I.J.; Whiteman, M.C. Personality Traits, 2nd ed.; Cambridge University Press: Cambridge, UK, 2003. [CrossRef]

26. Chu, X.; Ma, Z.; Li, Y.; Han, J. Agreeableness, extraversion, stressor and physiological stress response. Int. J. Soc. Sci. Stud. 2015, 3, 79-86. [CrossRef]

27. Goldstein, B.; Kotov, R.; Perlman, G.; Watson, D.; Daniel, N. Trait and facet-level predictors of first-onset depressive and anxiety disorders in a community sample of adolescent girls. Psych. Med. 2018, 48, 1282-1890. [CrossRef] [PubMed]

28. Gong, Y.; Sji, J.; Ding, H.; Zhang, M.; Kang, C.; Wang, K.; Yu, Y.; Wei, J.; Wang, S.; Shao, N.; et al. Personality traits and depressive symptoms: The moderating and mediating effects of resilience in Chinese adolescents. J. Affect. Disord. 2020, 265, 611-617. [CrossRef] [PubMed]

29. García, F.; Musitu, G. Autoconcepto Forma 5. AF-5. [Self-concept Form 5. SC-5]. TEA Ediciones. 2014. Available online: https://web.teaediciones.com/ejemplos/af-5_manual_2014_extracto.pdf (accessed on 20 October 2019).

30. World Medical Association. Declaration of Helsinki. Ethical principles for medical research involving human subjects. Jahrb. für Wiss. Und Ethik 2009, 14, 233-238. [CrossRef]

31. Maynard, B.R.; Solis, M.R.; Miller, V.L.; Brendel, K.E. Mindfulness-based interventions for improving cognition, academic achievement, behavior, and socioemotional functioning of primary and secondary school students. Campbell Syst. Rev. 2017, 13, 1-144. [CrossRef]

32. Güldal, Ş.; Satan, A. The effect of mindfulness based psychoeducation program on adolescents' character strengths, mindfulness and academic achievement. Curr. Psychol. 2020, 1-12. [CrossRef]

33. Lu, S.; Huang, C.C.; Rios, J. Mindfulness and academic performance: An example of migrant children in China. Child. Youth Serv. Rev. 2017, 82, 53-59. [CrossRef]

34. Macías, M.A.; Orozco, C.M.; Amarís, M.V.; Zambrano, J. Estrategias de afrontamiento individual y familiar frente a situaciones de estrés psicológico [Individual and family copying strategies when facing psychological stress situations]. Psicol. desde el Caribe 2013, 30, 123-145.

35. Gaeta González, M.L.; Martín Hernández, P. Estrés y adolescencia: Estrategias de afrontamiento y autorregulación en el contexto escolar [Stress and adolescence. Coping strategies and Self-Regulation in th School Context]. Stud. Rev. de Humanid. 2009, 15, 327-344.

36. Mammadov, S. Big Five personality traits and academic performance: A meta-analysis. J. Personal. 2021. [CrossRef]

37. Yoon, K.L.; Maltby, J.; Joormann, J. A pathway from neuroticism to depression: Examining the role of emotion regulation. Anxiety Stress Coping 2013, 26, 558-572. [CrossRef]

38. Andrés, M.L.; Stelzer, F.; Canet Juric, L.; Introzzi, I.M.; Rodríguez Carvajal, R.; Navarro Guzmán, J.I. Emotion regulation and academic performance: A systematic review of empirical relationships. Psicol. em Estudo 2017, 22, 299-311. [CrossRef]

39. Boekaerts, M.; Pekrun, R. Emotions and emotion regulation in academic settings. In Handbook of Educational Psychology; Routledge: New York, NY, USA, 2015; pp. 90-104.

40. Tus, J. Self-Concept, Self-Esteem, Self-Efficacy and Academic Performance of the Senior High School Students. Int. J. Res. Cult. Soc. 2020, 4, 45-59.

41. Kolnes, M.; Uusberg, A.; Konstabel, K. On the relationship between explicit and implicit self-concept of extraversion and neuroticism. J. Res. Personal. 2021, 90, 104061. [CrossRef]

42. Stieger, M.; Robinson, S.A.; Bisson, A.N.; Lachman, M.E. The relationship of personality and behavior change in a physical activity intervention: The role of conscientiousness and healthy neuroticism. Personal. Individ. Differ. 2020, 166, 110224. [CrossRef]

43. Hay, I.; Ashman, A.F. The development of adolescents' emotional stability and general self-concept: The interplay of parents, peers, and gender. Int. J. Disabil. Develop. Educ. 2003, 50, 77-91. [CrossRef]

44. Trigueros, R.; Padilla, A.M.; Aguilar-Parra, J.M.; Rocamora, P.; Morales-Gázquez, M.J.; López-Liria, R. The Influence of Emotional Intelligence on Resilience, Test Anxiety, Academic Stress and the Mediterranean Diet. A Study with University Students. Int. J. Environ. Res. Public Health 2020, 17, 2071. [CrossRef]

45. Karaman, K.; Lerma, E.; Cavazos, J.; Watson, J. Predictors of Academic Stress among College Students. J. Coll. Couns. 2019, 22, 41-55. [CrossRef]

46. Teixeira, R.J.; Brandão, T.; Dores, A.R. Academic stress, coping, emotion regulation, affect and psychosomatic symptoms in higher education. Curr. Psychol. 2021. [CrossRef] 
47. Lei, L.Y.C.; Ismail, M.A.A.; Mohammad, J.A.M.; Yusoff, M.S.B. The relationship of smartphone addiction with psychological distress and neuroticism among university medical students. BMC Psychol. 2020, 8, 97. [CrossRef]

48. Bai, Q.; Bai, S.; Dan, Q.; Lei, L.; Wang, P. Mother phubbing and adolescent academic burnout: The mediating role of mental health and the moderating role of agreeableness and neuroticism. Personal. Individ. Differ. 2020, 155, 109622. [CrossRef]

49. De la Fuente, J.; González-Torres, M.C.; Artuch-Garde, R.; Vera-Martínez, M.M.; Martínez-Vicente, J.M.; Peralta-Sánchez, F.J. Resilience as a Buffering Variable Between the Big Five Components and Factors and Symptoms of Academic Stress at University. Front. Psychiatry 2021, 12, 600240. [CrossRef] [PubMed]

50. De la Fuente, J.; Amate, J.; González-Torres, M.C.; Artuch, R.; García-Torrecillas, J.M.; Fadda, S. Effects of Levels of Self-Regulation and Regulatory Teaching on Strategies for Coping With Academic Stress in Undergraduate Students. Front. Psychol. $2020,11,22$. [CrossRef] [PubMed]

51. Sánchez-Álvarez, N.; Berrios-Martos, M.P.; Extremera, N. A Meta-Analysis of the Relationship between Emotional Intelligence and Academic Performance in Secondary Education: A Multi-Stream Comparison. Front. Psychol. 2020, 11, 1517. [CrossRef] [PubMed] 